only elements under examination. And first with regard to carbon and oxygen. Carbonic oxide burned in air gives a flame possessing a continuous spectrum. A mixture of carbonic oxide and oxygen burned from a platinum-tipped safety-jet also gives a more or less continuous spectrum, but the light of the spectrum has a tendency to group itself in ill-defined ridges. Carbonic oxide, however, ignited by the electric discharge in a semi-vacuous tube, gives a bright sharp spectrum. This spectrum was proved, by the simultaneous method of observation, to be that of carbon plus the spectrum of oxygen. With regard to carbon and sulphur almost the same remarks may be made. IBisulphide of carbon vapour burns in air with a bluish flame. Its spectrum is continuous. Mixed with oxygen and burned at the safety-jet, its flame still gives a continuous spectrum, though more distinctly furrowed than in the case of carbonic oxide; but when ignited by the electric current its spectrum is well defined, and is that of carbon plus the sulphur. That is to say, it is the spectrum of carbon plus the spectrum that is obtained from vapour of sulphur when ignited by the electric discharge in an otherwise vacuous tube."

"Having thus demonstrated that dissimilar compounds containing carbon emit, when sufficiently ignited, similar rays of light, I come to the conclusion that those rays are characteristic of ignited carbon vapour, and that the phenomena they give rise to on being refracted by a prism is the spectrum of carbon."

This question was next taken up by Morren. He wrote ${ }^{1}$ (in 1865 ) fifteen years ago :-

"A la réception de cet intéressant et substanticl Mémoirc, j'avoue que je ne regardai pas d'abord comme fondée l'assertion de M. Attfield. . . .

"Je me suis donc mis au travail avec la pensée préconcue de combattre l'assertion émise par le savant anglais; mais pas du tout, il résulte au contraire des expériences auxquelles je me suis livré que $\mathrm{M}$. Attfield a raison, et que c'est bien la vapeur du carbone qui donne le spectre indiqué plus haut. . .

"Si on fait brûler le cyanogène au mojen du chalunieau à deux courants, en faisant arriver au centre de la flamme du cyanogène un courant d'oxygène très-pur (cette condition est indispensable), on voit se produire un des plus beaux effets de combustion possible, et cette cxpérience est certainement une des plus magnifiques qu on puisse réaliser sur la combustion des gaz. Il se produit, au milieu de la flamme rosé-violâtre du cyanogène, une boule d'un blanc vert éboulissant qui rappelle la lumière électrique produitc par le courant de la pile entre deux charbons de cornue. Si le spectroscope est dirigé sur cette brillante lumière, on aperçoit, avec une splendeur merveilleuse, le même spectre de la partie bleuc des flammes hydrocarburcées. Ainsi donc c'est du charbon seul, mais à l'état de vapeur, qui forme cette boule brillante qui plus loin, par son union avec l'oxygène, va passer à l'état d'acid carbonique. Du restc ce spectre n'est pas seul; avec lui on voit, mais très effacé, le spectre spécial du cyanogène, et celui-ci tend de plus en plus à disparaître à mesure que l'oxygène arrive avec plus d'abondance et brûle de mieux en mieux le cyanogìne. Quant au spectre de l'azote, on ne l'aperçoit pas dans cette vive lumière. Le magnifique éclat de ce beau spectre, le plus beau qu'il m'ait été donné de voir, permet de bien comprendre l'aspect creusé et ombré avec une teinte croissante qu'on remarque dans les parties qui n'ont pas de raies brillantes, et même entre ces raies."

Four years later Dr. Watts devoted himself to this subject, and in 1869 his work was thus summarised by himself : ${ }^{2}$ -

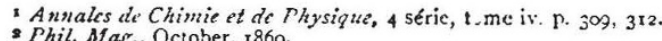
s Phil. Mfas., October, 1869 .
"This spectrum [that consisting of the flutings in question] may be obtained from the flame of any hydrocarbon, though in many cascs, owing to the faintness of the spectrum, only some of the groups can be recognised. In the flame of an ordinary I3unsen burner $\delta$ and $\epsilon$ are easily seen, $\gamma$ and $f$ are much fainter, and the red group cannot be detected.

" This spectrum is proved to be that of carbon, inasmuch as it can be obtained alike from compounds of carbon with hydrogen, with nitrogen, with oxygen, with sulphur, and with chlorine. I have obtained it, namely, from each of the following compounds:-olefiant gas, cyanogen, carbonic oxide, naphthalin, carbonic disulphide, carbonic tetrachloride, amylic alcohol, and marsh-gas."

That these conclusions, successively arrived at by Attfield, Morren, and Watts, are sound, I shall show in my next notice.

J. NORMAN LOCKYF.R

(To be continued.)

\section{SCIENCE IN PARLIAMENT}

THE House of Commons is now complete; all the boroughs and counties have made their choice, and the composition of the new Parliament has been and will be criticised from many points of view. So far as the interests of science and of what we conceive to be good education are concerne 1 , there is, we fear, little diference between the present House of Commons and its predecessor; just a thin ray of light athwart a cloud of darkness, a tiny morsel of knowledge in a mass of ignorance. This ignorance, however, we are bound to believe is not wilful ; we must admit that our new rulers are willing to be enlightened, unless in time they should show themselves otherwise disposed.

On this ground, as well as on others, it is to be lamented that one of the most eminent and useful scientific members of the House has lost his seat through some local caprice. The absence of Sir John Lubbock from the new Parliament is one we are sure every true lover of science will deplore. Where there is so much ignorance to be overcone, it seems to us we cannot have too many representatives of science in Parliament; and we are sure all who desire to sec science advanced in this country would welcome any chance of getting Sir John back to his old place. Such an opportunity has, some may think almost providentially, presented itself in the vacancy that has occurred in the representation of London University by the promotion of Mr. Lowe to "another place." Scveral candidates have been proposed for the vacant scat, but alongside of Sir John Lubbock all must strike an impartial onlooker as singularly unsuitable. The "doctors" have been attempting to put in a strong claim to have themsclves specially represented, supporting their cause, so far as London University is concerned, by somewhat shaky statistics. But medicine has no lack of friends in both Houses of Parliament; the claims which it has on the country are patent to all, and it is, moreover, included under the wider region of science. If the latter gets fair play from Government, medicine need have no fear that her claims will be ncglected. Already are two Scottish universities represented by Dr. Lyon Playfair, who is nothing if not medical. Not one of. our English universitics has a man of science as its representative, and it is surely important that an institution in which science holds so prominent 
a place as London University should have a scientific man for its representative. Sir George Jessel has for some reason a few strenuous advocates, who scem to forget that their candidate resigned his seat for Dover on the ground that it was contrary to the spirit of the act. Sir George is an excellent lawyer, but there are already too many of them in Parliament. Sir John Lubbock has already been fourteen years member of the Senate, and nearly eight vice-chancellor; thus by returning him not only would the London University confer a benefit on Parliament and the conntry at large, but at the same time would do the best they could for their own interests. We nced not here insist on the claims of Sir John as a man of science; his eminence in this department, as well as a man of business is, known to all. He is indeed so many-sided that he would represent as few others could the different facultics which combine to form the London University. His carecr in Parliament has been marked by a large number of measures which he has carried through I'arliament, all of them of a kind more or less affecting the alumni of London Lniversity, and several of them directly affecting those very medical men that would now turn thcir backs upon him. Sir John has been officially connected with various bodics and various movements having for their object the promotion of learning and science, and now we belicve he has had the great honour of being designated as President of the British Association for its jubilee mecting at York next year. We should have thought ilat for a body like the members of London University it vould have been unnecessary to point out Sir John Lubbock's claims upon them, and his peculiar fitness to represent them in Parliament. We are confident that all the scientific members of the institution will record their rntes in his favour, and by sending him to Parliament strungthen the hands of the few who are intelligently convinced of the necessity of introducing and carrying out thise reforms which are so much needed in the attitude of ( $\mathrm{row}$ crnment towards science and education.

\section{HURTZ'S "CHEIHSTRY"}

Elcmints of IIndern Chemistry. By Adolphe Wurtz. Translated and edited by TIm. H. Greene, M.D. (London: W. Swan Sonnenschein and Allen, I880.)

N WURTZ is one of the recognised leaders of 1. modern cienistry : a text-book from his pen is sure to be hailed with interest and pleasure.

The reputation of the author as an original thinker and worker in chemical science leads one to look for something more than the ordinary orthodox collection of oft-repeated facts in any work bearing his name. And the opening parges of the book before us are certainly very refreshing. Siizple and commonly-occurring facts are clearly and simply stated, and on these, as a basis, is aid at once the fourclation of chemical theory.

The leating features of the book are, clearness of statement, selection of typical ficts from among the vast array at the service of the chemical compiler, and devotion of a comparatively large space to chemical theory and to greneralisations which are usually dismissed in a few words in the ordinary text-book.

Perhaps the most remarkalsle feature of M. Wurtz's book is that, notwitlstanding that within less than 700 moderate-sized pages there is given an account of the leading properties of all the more important substances known to chemistry, the book is nevertheless exceedingly interesting and eminently readable. Probably this result could only be attained by a French writer.

In a very carly part of the book the modern theory of valency or equivalency is explained, and this theory pervades the whole of the work. The great objection to the book, considered as an exponent of modern chemistry, in our opinion, is this marked devotion to one favourite theory. The objection which ve should make to the book, considered more broadly as a scientific treatise, is that theoretical considerations are too much treated as identical with facts, and that facts are, secmingly, supposed to be explained when they are only stated in the language of that peculiar theory which finds in such expressions as "exchange of affinitics," "satisfaction of bonds," \&ic., an explanation of chemical phenomena. The theory of valency assumes that the molecular weights of those compounds which are employed in determinations of valency are known. But at present we know the molecular weights of gasifiable bodies only; hence no exact conclusions concerning valencies can be drawn from a study of non-gasifiable compounds. Nevertlieless $M$. Wurtz appears to regard the formula of many non-volatile metallic oxides as on an equal footing with those of such compounds as water, hydrochloric acid, $\mathcal{S}_{\mathrm{c} .}$, and as just as serviceable for determinations of clementary valencies.

Indeed we do not find given a clear definition of molecular weight as distinguished from atomic weight. Avogadro's hypothesis, it is true, is mentioned, but not clearly stated as the basis of the modern system of molecular weight determinations. And without a definition of molecular weight, clearly established, it is impossible to grasp the modern acceptation of the term atomic weight.

In such a work as this one might reasonably look for a statement of the results of the recent work, of first-rate importance, of Guldber: and Waage, and of Ostwald, on Chemical Affinity, morc especially as the subject of mass action is mentioned and Berthollet's laws are detailed.

The general subject of affinity is somewhat vaguely treated. Thermal chemistry scarcely finds any recognition in the work.

It maj seem invidious to mention faults of detail; but there are a few which, we think, might very profitably be corrected in a second edition.

The nomenclature of the oxyacids of sulphur is certainly erroneous : hyposulphurous acid- $\mathrm{H}_{2} \mathrm{SO}_{2}$-is called hydrosulphurous, and thiosulphuric- $\mathrm{H}_{2} \mathrm{~S}_{2} \mathrm{O}_{3}$-hyposulphurous. The nomenclature of the oxides of iodine is also peculiar, and the formulac of the known oxides are somewhat startling : perbromic acid is still enumerated among the oxyacids of bromine. Dry sulphuretted hydrogen is said to be energetically decomposed by iodinc. $\mathrm{SO}_{2}$ is called sulphurous oxide or sulphurous acid gas; and, last!y, Lavoisier is said to have determined the composition of water in 1785 .

That part of the book which deals with the carbon compounds is not so satisfactory as the portion treating of inorganic chemistry. The classification is most unnatural, and the treatment of many important groups, $c . s .$, the alcohols and terpenes, is unsatisfactory.

We should not think it possible for an average student 